\section{Registration of ICGV-SM 86715 Peanut Germplasm}

ICGV-SM 86715 (Reg. no. GP-89, PI 598133), an improved virginia peanut (Arachis hypogaea L. subsp. hypogaea var. hypogaea) germplasm line, was developed by the SADC/ICRISAT (Southern African Development Community/International Crops Research Institute for the Semi-Arid Tropics) Groundnut Project in Malawi. It was released in 1992 as 'Veronica' for pure stand cultivation in Mauritius by the Mauritius Sugar Industry Research Institute (MSIRI), Reduit, Mauritius (5). It has resistance to rust (caused by Puccinia arachidis Speg.), late leafspot [caused by Phaeoisariopsis personata (Berk. \& M.A. Curtis) Arx; syn. Cercosporidium personatum (Berk. \& M.A. Curtis) Deighton], and pepper spot [caused by Leptosphaerulina crassiasca (Sechet) C.R. Jackson \& D.K. Bell]. It was also found free from early leafspot (caused by Cercospora arachidicola S. Hori) in Mauritius.

ICGV-SM 86715 is derived from a cross between Arachis hypogaea subsp. hypogaea var. hypogaea cv. Makulu Red and a tetraploid interspecific backcross derivative, ('Samaru 38'/Arachis diogoi Hoehne (GKP 10602)//'Samaru 61'. It was developed by following repeated bulk selections. At the time of harvest, the selected plants were grouped into three bulks based on similarity of their growth habit, maturity, and reaction to foliar diseases (leaf spots and rust), and each bulk was further evaluated in separate rows. This process of selection was continued until the selected bulks stabilized. One such stabilized bulk was designated as ICGV. SM 86715

In trials conducted in Malawi at two locations during the 19871988 and 1988-1989 crop seasons, ICGV-SM 86715 (with mean seed yield of $1.61 \mathrm{t} \mathrm{ha}^{-1}$ ) outyielded the local cultivars 'Chitembana' by $388 \%$ (mean seed yield, $0.33 \mathrm{t} \mathrm{ha}^{-1}$ ) and 'Mawanga' by $41 \%$ (mean seed yield, $1.14 \mathrm{tha}^{-1}$ ). In regional trials conducted during the same period in Mozambique, Swaziland, and Zambia, it outyielded the local cultivars 'Egret' by $26.7 \%$ and 'Mani Pintar' by $13.6 \%$. In four trials conducted at three locations in Mauritius during the 1988 and 1989 crop seasons, it had a mean pod yield advantage of $65.3 \%$ over 'Cabri' and $23.5 \%$ over DHT 200 . In these trials, the pod yield of ICGV-SM 86715 ranged from 2.4 to $4.7 \mathrm{tha}^{-1}$, with a mean of $3.52 \mathrm{t} \mathrm{ha}^{-1}(2,3)$.

In nine trials conducted on experiment stations and on-farm in Mauritius, ICGV-SM 86715 was rated 2.0 for rust on a scale of 0 to 9 (where $0=$ immune and $9=$ very highly susceptible), compared with a rating of 5.8 for Cabri $(2,4)$. In six on-farm trials, ICGV-SM 86715 did not show any incidence of early leafspot, compared with a score of 5.0 for Cabri and 4.0 for DHT 200 on a similar scale of 0 to 9 (4). ICGV-SM 86715 was also found free from late leafspot, compared with a score of 4.0 for both Cabri and DHT 200 on a similar scale of 0 to 9 at three experiment stations in Mauritius (2). In the same six on-farm trials conducted in Mauritius, ICGV-SM 86715 showed only slight incidence of pepper spot, compared with moderate incidence in Cabri (4). In Swaziland, ICGV-SM 86715 maintained its rust and late leafspot resistance superiority over the local cultivars Egret and Mani Pintar. Compared with Cabri, ICGV-SM 86715 is less susceptible to leaf tier (Lamprosema indicata F.) infestation in Mauritius (5).

ICGV-SM 86715 has a Decumbent 3 growth habit (1), alternate branching, and medium-sized elliptic green leaves. 1t has, on average, seven primary and four secondary branches. It matures in 117 to $159 \mathrm{~d}$, depending on the season and location in southern Africa. It has medium-sized pods ( $34.7 \mathrm{~mm}$ average length, 11.2 $\mathrm{mm}$ average width) with prominent reticulation, moderate beak, and moderate to deep constriction. The majority of pods are twoor one-seeded (occasionally, three-seeded), with average meat content of $64 \%$. Seeds are red, weigh $57 \mathrm{~g} 100$ seed $^{-1}$, and contain $48 \%$ oil.
Breeder seed of ICGV-SM 86715 is maintained by the SADC/ ICRISAT Groundnut Project, Malawi. Limited quantities of seed are available upon request from the Genetic Resources Division, ICRISAT Asia Center. Seed of ICGV-SM 86715 is also deposited with the National Seed Storage Laboratory, $1111 \mathrm{~S}$. Mason St.,t Fort Collins, CO 80521-4500.

\section{J. P. Moss, A. K. Singh, S. N. Nigam, G. L. Hildebrand, N. Govinden, F. M. ISMAEL, P. Subrahmanyam, AND L. J. REDDY* (6) \\ References and Notes}

1. IBPGR and ICRISAT 1992. Descriptors for groundnut. IBPGR, Rome, Italy, and ICRISAT, Patanchen, India.

2. MSIRI. 1990. Annual report 1989. p. 66-68. Mauritius Sugar Industry Res. Inst., Reduit, Mauritius.

3. MSIRI. 1991. Annual report 1990. p. 76. Mauritius Sugar Industry Res. Inst., Reduit, Mauritius.

4. MSIRI. 1992. Annual report 1991. p. 69. Mauritius Sugar Industry Res. Inst., Reduit, Mauritius.

5. MSIRI. 1993. Annual report 1992, p. 68-69. Mauritius Sugar Industry Res. Inst., Reduit, Mauritius.

6. J.P. Moss, Ealachan Bhana, Clachan Seil, By Oban, Argyll, PA 344 TL, Scotland, UK; A.K. Singh, S.N. Nigam, and L.J. Reddy, ICRISAT Asia Center, Patancheru 502324, AP, India; P. Subrahmanyam, SADC/ICRISAT Groundnut Project, Lilongwe, Malawi; G.L. Hildebrand, Rattray Amold Res. Stn., Chisipite, Harare, Zimbabwe; N. Govinden and F.M. Ismael, Mauritius Sugar Industry Res. Inst. (MSIRI), Reduit, Mauritius. ICRISAT Joumal Article no. JA 2037. Registration by CSSA. Accepted 31 July 1997. *Corresponding author (I.reddy@cgnet.com).

We gratefully acknowledge the pathology and entomology division staff of MSIRI for the information on reaction of ICGV-SM 86715 to various diseases and insect pests at various locations in Mauritius.

Published in Crop Sci. 38:572 (1998).

\section{Registration of ICGV-SM 85048 Peanut Germplasm}

1CGV-SM 85048 (Reg. no. GP-90, Pl 598134), an improved spanish peanut (Arachis hypogaea L. subsp. fastigiata var. vu/garis) germplasm, was developed at the SADC/ICR1SAT (Southern African Development Community/International Crops Research Institute for the Semi-Arid Tropics) Groundnut Project in Malawi. It was first tested at the Mauritius Sugar Industry Research Institute (MSIRI), Mauritius, in 1988. After evaluations in on-station and on-farm trials, it was released in 1992 as 'Stella' in Mauritius (8). It is suitable for cultivation both in sugarcane (Saccharum officinarum L.) interrows and in pure stands.

ICGV-SM 85048 originated from a double cross ['Goldin l'/ Faizpur 1-5//Manfredi/'M 13'] made in the 1980-1981 season at the Asia Center of ICRISAT, Patancheru, India. Goldin 1, a spanish cultivar and M 13, a large-seeded virginia (subsp. hypogaea var. hypogaea) cultivar, were released in the USA (4) and India (1), respectively. Faizpur 1-5 is a spanish breeding line from India. Manfredi (probably Manfredi 68) is a breeding line originating from Argentina. The $\mathrm{F}_{3}$ population from this cross was tested in the 1982-1983 season at the SADC/ICRISAT Groundnut Project, Malawi. The first selection for high pod yield and other desirable agronomic characteristics was visually made in the $F_{3}$ population at time of harvest. Selected plants were bulked together based on similar phenotypes. One such bulk was designated as $B_{1}$. This process of selection and bulking was repeated for the next two generations in the $B_{1}$ bulk after which the selected bulk stabilized. The full pedigree of ICGV-SM 85048 is [Goldin 1/Faizpur 1-5// Manfredi/M 13] $\mathrm{F}_{3}-\mathrm{B}_{1}-\mathrm{B}_{2}-\mathrm{B}_{1}$

ICGV-SM 85048 has an erect growth habit, sequential flowering, and elliptic light green medium-sized leaves (2). It has, on 
average, six primary branches and one secondary branch. The plant height and canopy width are about 29 and $33 \mathrm{~cm}$, respectively. The maturity period of ICGV-SM 85048 at Chitedze, Malawi, ranges from 116 to $126 \mathrm{~d}$. It has inainly two-seeded pods, which are characterized by absent to slight beak, slight to moderate constriction, and prominent reticulation and ridge. Pod length averages $29 \mathrm{~mm}$; pod width, $10 \mathrm{~mm}$. The testa of ICGV-SM 85048 is deep red. Seeds are round, with flat ends. Meat content ranges from 66 to $71 \%$, with an average of $69 \%$; the 100 -seed weight ranges from 30 to $41 \mathrm{~g}$, with an average of $34 \mathrm{~g}$. Seeds of ICGV-SM 85048 contain $26 \%$ protein and $54 \%$ oil with an oleic to linoleic fatty acid ratio of 1.1 (based on data of the 1994-1995 season at Chitedze, Malawi).

In various on-station yield trials conducted during the 19851986 to $1990-1991$ seasons at Chitedze, Malawi, 1CGV-SM 85048 recorded a pod yield advantage ranging from 3.4 to $66.1 \%$ with an average of $29.5 \%$ over the control cultivar Malimba. The pod yield of ICGV-SM 85048 in these trials ranged from 1.2 to $3.9 \mathrm{t}$ ha-1 and that of Malimba from 1.2 to $3.1 \mathrm{t} \mathrm{ha}^{-1}$. In the 1990-1991 SADC/ICRISAT regional yield trials conducted in Malawi, Namibia, Swaziland, and Zambia, the pod yield advantage of ICGV-SM 85048 ranged from 8.1 to $69.0 \%$, with an average of $36.2 \%$ (3).

ICGV-SM 85048 produced on average $39.4 \%$ more pod yield than 'Cabri', a local cultivar, in Mauritius on-station trials during 1989 and $1990(5,6), 41.5 \%$ more in on-farm trials in $1991(7)$, and $27.3 \%$ more in on-farm trials in $1992(8)$. The on-farm trials were conducted in sugarcane interrows.

ICGV-SM 85048 is resistant to web blotch (caused by Phoma arachidicola Marasas, G.D. Pauer \& Boerema) in Mauritius. But, similar to local cultivar Cabri, it is susceptible to rust (caused by Puccinia arachidis Speg.), late leafspot [caused by Phaeoisariopsis personata (Berk. \& M.A. Curtis) Arx; syn. Cercosporidium personatum (Berk. \& M.A. Curtis) Deighton], and pepper spot [caused by Leptosphaerulina crassiasca (Sechet) C.R. Jackson \& D.K. Bell] (5). In Malawi, it showed tolerance to early leaf spot (caused by Cercospora arachidicola $\mathrm{S}$. Hori) compared with the local cultivar Malimba (3). Compared with Cabri, ICGV-SM 85048 is less susceptible to leaf tier (Lamprosema indicata $F$.) infestation in Mauritius (8). 1ts reaction to other insect pests was not tested.

Breeder seed of ICGV-SM 85048 is maintained by the SADC/ ICRISAT Groundnut Project, Malawi. Limited quantities of seed are available upon request from the Genetic Resources Division, ICRISAT Asia Center. Seed of ICGV-SM 85048 is also deposited with the National Seed Storage Laboratory, 1111 Mason St., Fort Collins, CO 80521-4500.

S. N. NiGAM, * G. L. Hildebrand, K. R. Bock, F. M. ISMAEL, N. Govinden, P. Subrahmanyam, AND L. J. REDDy (9)

\section{References and Notes}

1. Basu, M.S., and P.S. Reddy. 1987. Groundnut varieties of India. Tech. Bull. 2. Natl. Res. Ctr. for Groundnut, Indian Council of Agric. Res., Junagadh, Gujarat, India.

2. IBPGR and ICRISAT. 1992. Descriptors for groundnut. Int. Board of Plant Genetic Resources, Rome, and Int. Crops Res. Inst. for the Semi-Arid Tropics, Patancheru, AP, India.

3. ICRISAT. 1997. Groundnut elite germplasm ICGV-SM 85048. ICRISAT Plant Material Description no. 74. ICRISAT, Patanchen, AP, India.

4. Isleib, T.G., J.C. Wynne, S.N. Nigam. 1994. Groundnut breeding. p. 552-617. In J. Smart (ed.) The groundnut crop: A scientific basis for improvement. Chapman \& Hall, London.

5. MSIRI. 1990. Annual report 1989. p. 66-68. Mauritius Sugar Industry Research Institute, Reduit, Mauritius.

6. MSIRI. 1991. Annual report 1990. p. 76. MSIRI, Reduit, Mauritius.

7. MSIRI. 1992. Annual report 1991. p. 69. MSIRI, Reduit, Mauritius.

8. MSIRI. 1993. Annual report 1992. p. 67-69. MSIRI, Reduit, Mauritius.

9. S.N. Nigam, Genetic Enhancement Div., ICRISAT Asia Crr., Patanchen 502 324, AP, India; G.L. Hildebrand, Seed Co-op, P.O. Box CH 142, Chisipite, Harare, Zimbabwe; K.R. Bock, formerly P.O. Box 641, Ukunda, Mombasa, Kenya; F.M. Ismael, and N. Govinden, Mauritius
Sugar Industry Research Institute, Reduit, Mauritius; P. Subrahmanyam and L.J. Reddy, SADC/ICRISAT Groundnut Project, Chitedze Agric. Res. Stn., P.O. Box 1096, Lilongwe, Malawi. Contribution of SADC/ICRISAT Groundnut Project, Malawi, MSIRI, Mauritius, and ICRISAT Asia Ctr., Patancheru. ICRISAT Journal Article no. JA 2036. Registration by CSSA. Accepted 31 July 1997. *Corresponding author (s.nigam@cgnet.com).

We gratefully acknowledge the pathology and entomology staff of MSIRI, Mauritius, for information on disease and insect pest reactions of this germplasm.

Published in Crop Sci. 38:572-573 (1998).

\section{Registration of VGP 10 Peanut Germplasm}

VGP 10 virginia peanut (Arachis hypogaea L. subsp. hypogaea var. hypogaea) germplasm (Reg. no. GP-88, PI 584772) was developed and released cooperatively by the USDA-ARS and the Virginia Agricultural Experiment Station in 1997. VGP 10 was released for large seed size, early maturity, and high oleic to linoleic fatty acid ratio. It was tested experimentally as VP 8129.

VGP 10 was developed from a single offtype plant selected in a plot of Chico (1). Based on observations of other plants in the plot and the breeding history of Chico in our program, VGP 10 is probably the result of a natural cross between Chico and an unknown pollen donor. Initial seed increase from the single-plant selection in 1981 was in the 1981 to 1982 USDA-ARS Puerto Rico winter nursery. Subsequent generations have been maintained by bulking seed from several plants each year. Plants are similar to 'NC 7' (7) with decumbent growth habit, green stems, dark green leaves, and no flowers on the main stem. VGP 10 matures earlier than NC 7, but not as early as 'VA 93B' (2). Pods are large, virginia market type, slightly constricted, slight to moderate in pod reticulation, and mostly two seeds per pod. Seeds have a tan testa color and weigh about $0.96 \mathrm{~g}$ seed $^{-1}$, compared with $0.92 \mathrm{~g}$ seed $^{-1}$ for NC 7. VGP 10 is acceptable commercially, but was not released as a cultivar due to lower yield potential compared with 'VA-C 92R' (6) and similar yield potential to other currently available cultivars such as NC 7 and NC 9 (8). VGP 10 is not resistant to any of the current disease and insect pathogens in Virginia.

Three-year (1991-1993) test averages over three digging dates in the Virginia and North Carolina Peanut Variety and Quality Evaluation Program $(3,4)$ have shown VGP 10 to have significantly $(P=0.05)$ more extra large kernels $(52 \%)$ than NC 7 $(45 \%)$, VA-C 92R (36\%), and NC $9(30 \%)$. The oleic to linoleic fatty acid ratio of seed from these tests $(3,5)$ was higher $(P=0.05)$ for VGP 10 (2.5) than for NC 7 (2.3), VA-C 92R (1.6), and NC 9 (1.4). VGP 10 should therefore have a longer shelf life than currently available cultivars, except possibly NC 7. Blanchability, as determined by percentage of whole blanched extra large seed, was slightly lower for VGP $10 .(80 \%)$ than for NC 7 (83\%). VGP 10 should be valuable germplasm to peanut breeders looking for a combination of long shelf life, large seed and pod size, and early maturity.

Seed of VGP 10 will be maintained by the USDA-ARS Southern Regional Plant Introduction Station (SRPIS), Griffin, GA. Small quantities of seed are available upon written request to R.N. Pittman, Peanut Curator, USDA-ARS, SRPIS, Griffin, GA 30223. Appropriate recognition should be given when this germplasm contributes to research or development of new cultivars.

\section{T. A. Coffelt* AND R. W. Mozingo (9)}

\section{References and Notes}

1. Bailey, W.K., and R.O. Hammons. 1975. Registration of Chico peanut germplasm. Crop Sci. 15:105.

2. Coffelt, T.A., D.M. Porter, and R.W. Mozingo. 1994. Registration of 'VA 93B' peanut. Crop Sci. 34:1126. 